\title{
THE RIGHT TO GENDER IDENTITY: THE BASIC PRINCIPLES FOR UNDERSTANDING AND LEGAL ENFORCEMENT
}

\author{
Tereziia Popovych, \\ Associate Professor of the Department of Theory and History of State and Law, \\ Uzhhorod National University. \\ Candidate of Law, Associate Professor \\ https://orcid.org/0000-0002-8333-3921 \\ Scopus ID: 57216397820 \\ ResearcherID: $A A H-4454-2019$ \\ (https://publons.com/researcher/3268166/popovych-tereziia-popovych-tp/) \\ buts_tereza@ukr.net
}

\section{Summary}

The purpose of the study lies in highlighting and analyzing the basic principles of understanding and legal support of gender identity as a special legal phenomenon.

Methodologically, this work is based on the system of methods, scientific approaches, techniques and principles with the help of which the realization of the research aim is carried out. There have been applied universal, general scientific and special legal methods.

The article reveals that one of the main characteristics of gender identity in the scientific literature is considered to be a person's acquisition of gender roles (that is, ways of behavior depending on people's positions in gender differentiation) and the development of gender self-awareness (id est, awareness of their similarities and differences with representatives of their gender, in contrast to the opposite). Exercising the right to gender identity, we can talk about both the possibility of changing the biological sex and (or) social gender, which is expressed in changing not only physical data, but also a person's consciousness, his or her worldview, social (in some cases - and legal) role in society, family ... social manners of gender (name, appearance, behavior model, etcetera). In addition, based on the international documents, one can single out general principles related to human rights and gender identity: universality; non-discrimination; personal autonomy; respect for human dignity, regardless of sexual orientation and gender identification.

Based on the conducted scientific research the author has come to certain conclusions. 1. Gender identity presupposes certain models of social behavior of a person in view of gender, which is determined by nature. Consequently, we are talking, first of all, about accepting or not accepting this fact. Thus, gender identity demonstrates the behavior of an individual in society, which is based on self-identification according to this individual's gender. 2 . The right to gender identity implies the ability of an individual to perform lawful actions that will serve for this person's self-identification on the basis of gender. In accordance with this, we talk about actions of a legal (the enforcement of the right and duties based on self-identification) and of a medical nature (the possibility of changing (correcting) gender). In other words, the right to gender identity means an individual's ability to freely act in society based on the social role with respect to which this individual identifies herself / himself on the basis of gender. 3. Despite the recommendatory nature of international legal acts in the field of ensuring the human right to gender identity, the international community is increasingly calling on states to take appropriate measures to properly comply with the principles of equality, non-discrimination, individual autonomy and respect for this individual dignity in realizing the right to gender identity and to ensure its proper legal regulation.

Key words: gender identity, the right to gender identity, gender change. 


\section{Introduction}

The vision of an individual's identity has philosophical (J. Butler, W. James, P. Ricoeur, Z. Freud, M. Foucault, K. Jaspers, etc.), psychological (R. Burns, E. Erickson, M. Klee et al.) and sociological (P. Berger, T. Luckmann, T. Parsons, A. Schutz, etc.) foundation. The phenomenon of gender identity began to be actively studied later (T. Bendas, Sh. Burn, M. Cordwell, L. Ozhigova, R. Stoller, etc.). The contemporary socio-humanitarian research, which is strenuously devoted to the issue of gender identity, has permeated the field of law as well, due to which today everyone's right to gender identity is increasingly gaining a foothold in the public consciousness (especially in European countries).

The very term "gender identity» was formed in the mid-1960s to indicate a strong inner sense of belonging to a male or female gender category (Moleiro, Pinto). One of the main characteristics of gender identity in the scientific literature is viewed as an individual's acquiring of gender roles (that is, ways of behavior depending on people's positions with regard to gender differentiation) and the development of gender self-awareness (awareness of their similarities and dissimilarities with representatives of the sex they belong to, as distinct from the opposite) (Tkalych, M. H., Zinchenko, T. P. \& Kasian A. P. 2020, p. 102).

The research in the field of psychology shows that there are the following approaches to understanding the grounds for the development of the phenomenon of gender identity: masculine / feminine attributes; gender-stereotyped personality traits; interests correlating with a person's gender; self-categorization of belonging to a particular gender (Wood, Eagly, 2015, p. 461-473). Notwithstanding these different approaches, the phenomenon of gender identity is becoming increasingly urgent both in terms of research as well as society's demand, including the need to improve national legislation in line with protecting the rights of individuals who are distinguished by gender.

\section{The comprehension of the right to gender identity.}

To define the notion of the right to gender identity, it is necessary first to directly provide a brief clarification with respect to the very un- derstanding of gender identity as a phenomenon. According to L. Ozhigova, gender identity is defined as the result of a complex interaction of organismic, social and psychological (personal per se) factors, in which with the formation and realization of gender identity, the regulating and sense-making role of the personality is enhanced (Ozhigova, 2006, p. 14).

M. V. Yusupova states that gender is the relationship, which was formed in a particular society, between the anatomy of an individual and the set of social roles, offered to him, that are associated with this arrangement. Gender identity reflects the individual's ability to limit himself / herself to the framework of the models which are offered to him / her for self-identification, it is also a constant process of identification that directly depends on the expectations which connect the individual with the social environment as well as with the interpretation of his / her behaviour provided by others (Yusupova, 2011, p. 9).

Gender identity, according to O. O. Voronina, is one of the types of social identity of the individual and the group. Based on congenital sexual characteristics, it is still not congenital. It is a process of realizing and accepting the definitions of masculinity and femininity that exist within the culture in which a person is born and grows up; it is the categorization of oneself as a representative of a male or female group, the learning and reproducing of gender-based roles, positions and representations (Voronina, 2012, p. 21-22).

T. V. Kubrychenko emphasizes that currently the phenomenon of gender identity is a complex, multilevel, multicomponent and integrative formation. Based on the analysis of various approaches to determining the components of gender identity, the researcher points out the following ones: cognitive, affective and conative (behavioural) components; biological sex, masculinity / femininity / androgyny as psychological characteristics of a person; the hierarchy of life values, goals and views; gender, gender-role and sexual identity; different kinds of gender characteristics (gender stereotypes, sexual preferences, sexual orientation, social experience and upbringing, etc.) (Kubrychenko, 2012, p. 327).

For instance, if we take into account the three-component approach to the phenomenon 
of gender identity (cognitive, affective and conative (behavioural)), it will include these: the cognitive component presents the awareness of belonging to a certain gender and the determination of an individual in the categories of masculinity / femininity, the degree of his / her compliance with the characteristics of a gender group; the affective component contains an assessment of psychological traits and peculiarities of the role behaviour and their compliance with the reference models of masculinity / femininity. The conative (behavioural) component reflects the presentation of a person as a representative of a gender group, and also reflects the means of solving identity crises based on the choice of means of behaviour in certain situations, depending on personally meaningful goals and values (Kletsina, 2004, p. 408).

Thus, based on the biological affiliation of a person to a certain sex (male or female), gender identity, nevertheless, shows the social side of the development of such a basis, not being limited to it. Gender identity includes certain models of social behavior in relation with the gender determined by nature. Accordingly, we are dealing with either acceptance or non-acceptance of it. Hence, gender identity demonstrates an individual's behavior in society which rests on self-identification based on gender.

Having briefly clarified the nature of gender identity, we can proceed with the analysis of the right to gender identity. According to L. Strus, the right to gender identity is individuals' ability, which is enshrined in the norms of law, to independently determine which gender they belong to (male, female, or a gender persons), and if necessary, take legal and medical actions to balance their self-identity (Strus, 2019, p. 55).

Therefore, A. S. Shalyhanova considers the right to gender identity as a measure of the person's probable behavior which consists in the possibility of self-determination with regard to belonging to the particular gender, performing certain actions in accordance with their own gender identity concerning changing the biological and (or) social gender, as well as the ability to require others to refrain from actions that violate this right. In the structure of this right the researcher distinguishes, respectively, the right to the biological gender change (correction) (the natural existence of an individual) and the right to the social gender change (the social being of a person). Thus, the right to gender identity is viewed as a personal non-property right of an individual (Shalyhanova, 2011, p. 276-277).

V. S. Herbut, within the framework of his thesis research, comes to the conclusion that in the field of sexual orientation and gender identity, it is not "the right to ..." that is more successful, but "the right to freedom ...", because we are talking about the exclusive authority and competence of a person on their sexual orientation and gender identity, autonomy and self-determination in this area, and the fundamental nature of this right. The researcher determines the scope of this right as «the ability of a person to define themselves in relation to any types of sexual orientation and gender identity, meeting the needs related to this on the basis of the principles of equality and non-discrimination» (Herbut, 2018, p. 92-93).

Consequently, the right to gender identity entails the possibility to undertake lawful actions which serve for self-identification based on gender. In other words, the right to gender identity means a person's ability to freely act in society on the basis of the social role by which she identifies herself on the basis of gender. Accordingly, the point is about actions of a legal (the implementation of rights and obligations based on self-identification, the social gender change) and medical nature (the possibility of changing (correcting) the biological gender). In other words, the right to gender identity means an individual's ability to freely act in society on the basis of the social role he / she identifies himself / herself with in view of gender.

\section{The legal enforcement of the right to gender identity: international and national aspects}

Currently in the field of international legal enforcement of the right to gender identity, there are a number of international legal documents at the level of the UN and the Council of Europe, which, although are of a recommendatory nature, still play an important role serving as a kind of guidelines on establishing the legislative bases and practice of states' activities in the direction of enforcing the corresponding right, non-discrimination on the grounds of gender, 
etc. Among the above-mentioned documents there are, in particular: the Yogyakarta Principles (the Principles for applying the International Human Rights Law on Sexual Orientation and Gender Identity), developed by a group of international human rights experts and promulgated in March 2007 at the meeting of the UN Human Rights Council; Resolution of the Parliamentary Assembly of the Council of Europe «Discrimination on the grounds of sexual orientation and gender identity» of 2010; Recommendation of the Committee of Ministers of the Council of Europe «On measures to combat discrimination on grounds of sexual orientation or gender identity" of 2010. In addition, we are talking about a number of documents at the level of the UNO (Human Rights Resolutions, Reports of the High Commissioner for Human Rights) and the Council of Europe (Reports of the Commissioner for Human Rights), which are periodically published as a reaction to discrimination on the basis of sexual orientation and gender identity in different regions of the world, as well as a call to states to take appropriate measures to prevent this discrimination. The practice of the European Court of Human Rights in the field of protecting individuals' gender identity rights is also significant because it serves as a guideline towards understanding the development and strengthening of the participation of the member states of the Council of Europe in this area of social relations.

So for example, the Yogyakarta Principles contain a wide range of human rights standards in terms of their applicability to issues of sexual orientation and gender identity. Each of the principles (29) includes, inter alia, recommendations to states on how to ensure these rights. Gender identity according to this international document is defined as «a person's deep awareness of the internal and individual characteristics of gender, which may or may not coincide with birth gender, including the individual sense of their body (may be accompanied by changing appearance or physiological functions by medical, surgical or other means) and other manifestations such as clothing, speech and behavior» (Yogyakarta Principles, 2007).

I. Ya. Seniuta believes that, based on international documents, it is possible to identify general principles related to human rights and gender identity: 1) universality - it provides for the right of individuals of any sexual orientation and gender identity to possess the whole spectrum of rights and obligations on a full-scale basis; 2) equality - it involves the formulation of equality of rights and freedoms of individuals of any sexual orientation and gender identification, their equality before the law, providing them with equal opportunities; 3) non-discrimination - it envisages the right of everyone to exercise their rights and freedoms without discrimination on the grounds of sexual orientation and gender identification; 4) an individual's autonomy - it presupposes everyone's right to independently determine their sexual orientation and gender identity; 5) respect for human dignity regardless of sexual orientation and gender identification (Seniuta, 2015, p. 285).

Hence, despite the recommendatory nature of international legal acts in the field of ensuring the human right to gender identity, it should nevertheless be noted that the international community is increasingly calling on states to take appropriate measures on the proper observation of the principles of equality, non-discrimination, individuals' autonomy and respect for their dignity while implementing gender identity right and provide its proper legal regulation.

As for the Ukrainian experience of normative provision of the human right to gender identity, we are talking primarily of the provisions of the Fundamental Law of the state, which, in particular, in Art. 24 enshrines the principle of non-discrimination on various grounds (The Constitution of Ukraine, 1996). And, although the Constitution in this norm does not clearly indicate the attributes of sexual orientation and gender identification, nevertheless the wording "or other attributes» may mean, inter alia, the indicated attributes. Similar to these constitutional provisions, the Law of Ukraine «On principles of preventing and combating discrimination in Ukraine» does not specify attributes of sexual orientation and gender identification in defining the notion of "discrimination», fixing only "other attributes that were, are and can be valid or presumed» (On the principles of preventing and combating discrimination in Ukraine, 2012). However, we emphasize the admissibility of including also attributes of sexual orientation and gender identity to «other attributes». 
It should be added here that a significant number of states, like Ukraine with its experience in the field of non-discrimination, do not enshrine clearly the attributes of sexual orientation and gender identity as attributes of discrimination in their respective legal acts. With regard to the above mentioned such "gaps" are bridged by the practice of the European Court of Human Rights and the Inter-American Court of Human Rights, from whose point of view the indicated attributes at the regional international level are recognized as the protected categories in the sense of understanding discrimination (Lau, 2018, p. 18).

Additionally, Art. 51 of the Fundamentals of the Legislation of Ukraine on Health Care provides the right of the patient, subject to compliance with the established medico-biological and socio-psychological indications, to access health care facilities for medical intervention in order to change (correct) this patient's gender. In this case, a person, subject to gender change, is issued a medical certificate, on the basis of which the issue of changes in this person's legal status is further resolved (Fundamentals of the legislation of Ukraine on health care, 1992).

In pursuance to the provision of Art. 51 of the Fundamentals of the Legislation of Ukraine on Health Care in Ukraine, the Ministry of Health of Ukraine adopted initially the Decree «On providing medical care to persons who need gender change (correction)» dated March 15, 1996 (On the provision of medical care to persons in need of gender reassignment, 1996). Later the Decree "On the improvement of medical care provided to persons who need gender change (correction)» dated February 03, 2011 was adopted by the Ministry of Health of Ukraine (On improving the provision of medical care to persons in need of gender reassignment, 2011). Currently the Decree of the Ministry of Health of Ukraine «On the establishment of medical, biological and socio-psychological indications for gender change (correction) and approval of the form of supporting documentation and instructions for its completion» dated October 05, 2016 (About establishment of medico-biological and social-psychological indications for change (correction) of sexuality and the statement of the form of the primary accounting documentation and the instruction on its filling, 2016). A num- ber of adopted acts, which are further improved by the Ministry of Health Care of Ukraine, aim at determining the procedure for medical care provided to persons who need gender change (correction), show the importance of this sphere of social relations for the state and the need to determine its key aspects in order to avoid possible abuses because human health and life (physical and psychological) are at stake.

\section{Conclusions}

Therefore, based on the conducted research we can state at least the following. 1 . Gender identity includes certain models of social behavior in relation with the gender determined by nature. Accordingly, we are dealing with either acceptance or non-acceptance of it. Hence, gender identity demonstrates an individual's behavior in society which rests on self-identification based on gender. 2 . The right to gender identity entails the possibility to undertake lawful actions which serve for self-identification based on gender. In other words, the right to gender identity means a person's ability to freely act in society on the basis of the social role by which she identifies herself on the basis of gender. Accordingly, the point is about actions of a legal (the implementation of rights and obligations based on self-identification, the social gender change) and medical nature (the possibility of changing (correcting) the biological gender). In other words, the right to gender identity means an individual's ability to freely act in society on the basis of the social role he / she identifies himself / herself with in view of gender. 3. Despite the recommendatory nature of international legal acts in the field of ensuring the human right to gender identity, it should nevertheless be noted that the international community is increasingly calling on states to take appropriate measures on the proper observation of the principles of equality, non-discrimination, individuals' autonomy and respect for their dignity while implementing gender identity right and provide its proper legal regulation.

\section{Bibliography:}

1. Воронина, О.А. (2012) Гендерные аспекты идентичности. Человек, 6, С. 15-31.

2. Гербут, В. С. (2018) Право на сексуальну орієнтацію та гендерну ідентичність: сутнісний зміст та гарантії 
захисту (дис. ... канд. юрид. наук: 12.00 .02 - конституційне право; муніципальне право). Ужгород, 266 с.

3. Джокякартські принципи (Принципи застосування міжнародно-правових норм про права людини щодо сексуальної орієнтації та гендерної ідентичності) (2007).URL: https://www.refworld.org/cgi-bin/texis/vtx/ rwmain/opendocpdf.pdf?reldoc $=y \&$ docid $=48244 \mathrm{e} 952$ (дата звернення: 23.10.2020 року).

4. Клёцина, И.С. (2004) Психология гендерных отношений: Теория и практика. СПб.: Алетейя, 408 с.

5. Конституція України (1996): Закон України № 254к/96-ВР. Відомості Верховної Ради України. 1996, № 30, Ст. 141.

6. Кубриченко, Т. В. (2012) Ідентичність особистості в гендерному вимірі. Науковий вісник Львівського державного університету внутрішніх справ. Серія психологічна, 2, 323-331.

7. Ожигова, Л. Н. (2006) Гендерная идентичность личности и смысловые механизмы ее реализации (автореф. дисс. ... д-ра психол. наук: спец. 19.00.01) Краснодар, 46 с.

8. Основи законодавства України про охорону здоров’я (1992): Закон України № 2801-XII. Відомості Верховної Ради України. 1993, 4, Ст. 19.

9. Про встановлення медико-біологічних та сочіально-психологічних показань для зміни (корекціі) статевої належності та затвердження форми первинної облікової документації й інструкції щодо Iï заповнення (2016): Наказ Міністерства охорони здоров'я України № 1041. URL: https://zakon.rada. gov.ua/laws/show/z1589-16\#Text (дата звернення: 23.10.2020 року).

10. Про засади запобігання та протидії дискримінації в Україні» не уточнює при визначенні поняття «дискримінації (2012): Закон України № 5207-VI. Відомості Верховної Ради України. 2013, 32, Ст. 412.

11. Про надання медичної допомоги особам, що потребують зміни (корекціі) статевої належності (1996): Наказ Міністерства охорони здоров'я України № 57. URL: https://zakon.rada.gov.ua/laws/show/z027996\#Text (дата звернення: 23.10.2020 року).

12. Про удосконалення надання медичної допомоги особам, що потребують зміни (корекиіі) статевої належності (2011): Наказ Міністерства охорони здоров'я України № 60. URL: https://zakon.rada.gov.ua/laws/show/ z0239-11\#Text (дата звернення: 23.10.2020 року).

13. Сенюта, И. Я. (2015) Право на гендерную идентичность: этико-правовые аспекты. Биомедицинское право в России и за рубежом: монография / Г.Б. Романовский, Н.Н. Тарусина, А.А. Мохов и др. М.: Проспект. С. 283-304
14. Струс, Л. (2019) Гендерна ідентичність особи. European political and law discourse, 6, 51-55.

15. Ткалич, М. Г., Зінченко, Т. П. \& Касьян, А. П. (2020) Гендерна ідентичність особистості: зміст, структура, гендерно-рольова диференціація. Psychological journal, 6, 101-109.

16. Шалиганова, А. С. (2011) Щодо правової природи та змісту права на гендерну ідентичність. Право і безпека, 3, 274-279

17. Юсупова, М. В. (2011) Социально-философские основания конструирования гендерной идентичности (автореф. дисс. ... канд. филос. наук: спец. 09.00.11). Чебоксары, 24 с.

18. Lau, H. (2018) Sexual orientation and gender identity discrimination. Comparative discrimination law, 2, 1-52.

19. Moleiro, C. \& Pinto, N. Sexual orientation and gender identity: review of concepts, controversies and their relation to psychopathology classification systems. URL: https://www. frontiersin.org/articles/10.3389/fpsyg.2015.01511/full (дата звернення: 27.10.2020 року).

20. Wood, W. \& Eagly, A. (2015) Two traditions of research on gender identity. Sex Roles, 73, 461-473.

\section{References:}

1. Voronina, O. A. (2012). Gendernye aspekty identichnosti [Gender aspects of identity]. Chelovek, 6, 15-31. [in Russian].

2. Herbut, V. S. (2018). Pravo na seksualnu oriientatsiiu ta hendernu identychnist: sutnisnyi zmist ta harantii zakhystu [The right to sexual orientation and gender identity: substantive content and guarantees of protection] (Doctor's thesis). Uzhhorod. [in Ukrainian].

3. Dzhok'iakartski pryntsypy (Pryntsypy zastosuvannia mizhnarodno-pravovykh norm pro prava liudyny shchodo seksualnoi oriientatsii ta hendernoi identychnosti) [Yogyakarta Principles (Principles for the Application of International Human Rights Law on Sexual Orientation and Gender Identity)]. (2007). Available from: https://www. refworld.org/cgi-bin/texis/vtx/rwmain/opendocpdf. pdf?reldoc $=y \&$ docid=48244e952. [in Ukrainian].

4. Kletsina, I. S. (2004). Psikhologiya gendernykh otnosheniy: Teoriya i praktika [Psychology of Gender Relations: Theory and Practice]. SPb.: Aleteyya. [in Russian].

5. Konstytutsiia Ukrainy [The Constitution of Ukraine] (1996) № 254k/96-VR. Vidomosti Verkhovnoi Rady Ukrainy, 30,141.

6. Kubrychenko, T. V. (2012). Identychnist osobystosti v hendernomu vymiri [Personality identity in the gender dimension]. Naukovyi visnyk Lvivskoho derzhavnoho universytetu vnutrishnikh sprav. Seriia psykholohichna, 2, 323-331.

7. Ozhigova, L. N. (2006). Gender identity of the person and semantic mechanisms of its realization [Gender identity 
of a person and semantic mechanisms of its implementation] (Doctor's thesis). Krasnodar. [in Russian].

8. Osnovy zakonodavstva Ukrainy pro okhoronu zdorov'ia [Fundamentals of the legislation of Ukraine on health care] (1992) № 2801-Khll. Vidomosti Verkhovnoi Rady Ukrainy, 4, 19.

9. Pro vstanovlennia medyko-biolohichnykh ta sotsialno-psykholohichnykh pokazan dlia zminy (korektsii) statevoi nalezhnosti ta zatverdzhennia formy pervynnoi oblikovoi dokumentatsii y instruktsii shchodo yii zapovnennia [About establishment of medico-biological and social-psychological indications for change (correction) of sexuality and the statement of the form of the primary accounting documentation and the instruction on its filling] (2016). Available from: https://zakon.rada.gov.ua/ laws/show/z1589-16\#Text

10. Pro zasady zapobihannia ta protydii dyskryminatsii $\checkmark$ Ukraini [On the principles of preventing and combating discrimination in Ukraine] (2012). № 5207-VI. Vidomosti Verkhovnoi Rady Ukrainy, 2013, 32, 412.

11. Pro nadannia medychnoi dopomohy osobam, shcho potrebuiut zminy (korektsii) statevoi nalezhnosti [On the provision of medical care to persons in need of gender reassignment] (1996). № 57. Available from: https:// zakon.rada.gov.ua/laws/show/z0279-96\#Text

12. Pro udoskonalennia nadannia medychnoi dopomohy osobam, shcho potrebuiut zminy (korektsii) statevoi na- lezhnosti [On improving the provision of medical care to persons in need of gender reassignment] (2011). № 60 . Available from: https://zakon.rada.gov.ua/laws/show/ z0239-11\#Text

13. Senyuta, I. Ya. (2015) Pravo na gendernuyu identichnost: etiko-pravovye aspekty [The right to gender identity: ethical and legal aspects]. Biomeditsinskoe pravo $v$ Rossii i za rubezhom: monografiya / G.B. Romanovskiy, N.N. Tarusina, A.A. Mokhov i dr. M.: Prospekt [in Russian].

14. Strus, L. (2019) Henderna identychnist osoby [Gender identity of a person]. European political and law discourse, 6, 51-55. [in Ukrainian].

15. Tkalych, M. H., Zinchenko, T. P. \& Kasian A. P. (2020) Henderna identychnist osobystosti: zmist, struktura, henderno-rolova dyferentsiatsiia [Gender identity of the individual: content, structure, gender-role differentiation]. Psychological journal, 6, 101-109. [in Ukrainian].

16. Shalyhanova, A. S. (2011) Shchodo pravovoi pryrody ta zmistu prava na hendernu identychnist [Regarding the legal nature and content of the right to gender identity]. Pravo i bezpeka, 3, 274-279. [in Ukrainian].

17. Yusupova, M. V. (2011) Sotsialno-filosofskie osnovaniya konstruirovaniya gendernoy identichnosti [Socio-philosophical foundations for the construction of gender identity] (Doctor's thesis). Cheboksary. [in Russian].

\title{
ПРАВО НА ГЕНДЕРНУ ІДЕНТИЧНІСТЬ: ОСНОВНІ ЗАСАДИ РОЗУМІННЯ ТА ПРАВОВОГО ЗАБЕЗПЕЧЕННЯ
}

\author{
Терезія Попович, \\ дочент кафедри теорії та історії держави і права \\ ДВНЗ «ужгородський національний університет» \\ кандидат юридичних наук, доцент, \\ https://orcid.org/0000-0002-8333-3921 \\ Scopus ID: 57216397820 \\ ResearcherID: $A A H-4454-2019$ \\ (https://publons.com/researcher/3268166/popovych-tereziia-popovych-tp/) \\ buts_tereza@ukr.net
}

\section{Анотація}

Мета дослідження полягає у висвітленні та аналізі основних засад розуміння та правового забезпечення гендерної ідентичності як особливого правового феномену.

Методологічну основу даного дослідження складає система методів, наукових підходів, прийомів та принципів, котрі були спрямовані для реалізації цілей дослідження. Застосовувались універсальні, загальнонаукові та спеціально-юридичні методи. 
У статті досліджено, що однією з основних характеристик гендерної ідентичності в науковій літературі визнається засвоєння особистістю гендерних ролей (тобто способів поведінки залежно від позицій людей у статевій диференціаціі) і розвиток гендерної самосвідомості (тобто усвідомлення своєї схожості й відмінності з представниками своєї статі, на відміну від протилежної). Реалізовуючи право на гендерну ідентичність, може йти мова як про можливість зміни біологічної статті, так і (або) соціальної, що виражається у зміні не лише фізичних даних, але й свідомості людини, ії світогляду, соціальної (у деяких випадках - і юридичної) ролі у суспільстві, сім'ї ... соціальних манер статі (імені, зовнішності, моделі поведінки тощо). Окрім цього, виходячи з міжнародних документів, можливо виділити загальні принципи, повязані з правами людини та гендерною ідентичністю: універсальність; недискримінація; автономія особи; повага до гідності людини незалежно від ії сексуальної орієнтації та гендерної ідентифікації.

На підставі проведеної наукової розвідки автор прийшов до певних висновків. 1. Гендерна ідентичність передбачає ті чи інші моделі соціальної поведінки особи щодо статевої належності, яка ій природно дана. Тобто передусім мова йде про прийняття чи неприйняття такої природності. Таким чином, гендерна ідентичність демонструє поведінку особи в суспільстві, в основі якої лежить самоідентифікація за їі статевою належністю. 2. Право на гендерну ідентичність передбачає можливість особи вчиняти правомірні дії, які слугуватимуть для ії самоідентифікації на основі статевої приналежності. Відповідно до цього йдеться про діі юридичного (реалізація відповідних прав та обов'язків) та медичного характеру (можливість зміни (корекції) біологічної статі). Іншими словами, право на гендерну ідентичність означає можлиість особи вільно діяти в суспільстві на основі тієї соціальної ролі, з якою вона себе ідентифікує. 3. Незважаючи на рекомендаційний характер міжнародно-правових актів у сфері забезпечення права особи на гендерну ідентичність, міжнародне співтовариство все частіше закликає держави вживати відповідних заходів щодо належного дотримання принципів рівності, недискримінації, автономії особи та поваги до їі гідності при реалізації права на гендерну ідентичність та надавати йому належну правову регламентацію.

Ключові слова: гендерна ідентичність, право на гендерну ідентичність, зміна статі. 